\title{
Pengaruh Beberapa Jenis Bokashi dan Trichoderma spp. terhadap Pertumbuhan dan Hasil Tanaman Jagung Manis pada Tanah Alluvial
}

\author{
Effect of Several Types of Bokashi and Trichoderma spp. on Growth and Results of \\ Sweet Corn Plants on Alluvial Soils \\ Indah Permayani $^{1 *}$, Radian ${ }^{1}$, Tris Haris Ramadhan ${ }^{1}$ \\ ${ }^{1}$ Program Studi MagisterAgroteknologi, Fakultas Pertanian, Universitas Tanjungpura \\ Jl. Prof. Dr. H. Hadari Nawawi, Pontianak \\ *Email korespondensi: indah_mooi@gmail.com
}

Diterima: 20 Desember 2019 / Disetujui: 19 Februari 2020

\begin{abstract}
Efforts to meet the needs of sweet corn can be done by increasing production. One of them by increasing soil fertility is by giving bokashi and Tricodherma. This research includes bokashi and trichoderma types on the growth and productivity of maize. Tests using factorial randomized block design (RBD). The results showed that the interaction of bokashi with the addition of Trichoderma + biological fertilizer enriched by microbes significantly affected the growth of plant height, number of leaves, dry weight and yield of corn. The best growth and yield is achieved in the bokashi treatment of chicken manure with the addition of trichoderma and biological fertilizer.
\end{abstract}

Keywords:chicken manure; cow dung; fish waste; organic fertilizer

\begin{abstract}
ABSTRAK
Upaya untuk memenuhi kebutuhan jagung manis dapat dilakukan dengan meningkatkan produksi. Salah satunya dengan meningkatkan kesuburan tanah adalah dengan pemberian bokashi dan Tricodherma. Penelitian ini meliputi jenis bokashi dan trichoderma terhadap pertumbuhan dan produktivitas tanaman jagung. Pengujian menggunakan rancangan acak kelompok (RAK) Faktorial. Hasil penelitian menunjukkan bahwa Interaksi bokashi dengan penambahan Trichoderma + pupuk hayati yang diperkaya mikroba berpengaruh nyata terhadap pertumbuhan tinggi tanaman, jumlah daun, berat berangkasan kering dan hasil tanaman jagung. Pertumbuhan dan hasil produksi yang paling baik dicapai pada perlakuan bokashi kotoran ayam dengan penambahan trichoderma dan pupuk hayati.
\end{abstract}

Kata kunci: kotoran ayam, kotoran sapi, limbah ikan, pupuk organik

\section{PENDAHULUAN}

Permintaan jagung terus meningkat dari tahun ke tahun sejalan dengan meningkatnya jumlah penduduk dan industri. Dari hasil proyeksi Sudaryanto, Kustiari dan Saliem (2010) yang berdasarkan pada pertumbuhan penduduk, pendapatan, tren diversifikasi dan preferensi pangan masyarakat, perubahan harga, dan areal lahan garapan yang tersedia, maka proyeksi permintaan jagung 2010-2050 cenderung meningkat sebesar $0,68 \%$ setiap tahun. Produksi komoditas jagung di Kabupaten Mempawah tahun 2014 mengalami peningkatan dibandingkan tahun 2013 yakni sebesar 177, 35 persen. Tanaman jagung memiliki kontribusi yang cukup potensial di Kabupaten Mempawah. Tanaman jagung memberikan kontribusi terbesar kedua setelah ubi kayu dengan total produksi sebesar 1,38 ribu ton atau 13,35 persen dari total produksi tanaman palawija di Kabupaten Mempawah tahun 2014. Pada tahun 2014, secara keseluruhan luas panen tanaman palawija di Kabupaten Mempawah mengalami peningkatan dibandingkan tahun 2013, yaitu sekitar 48, 04 persen. Komoditas yang mengalami peningkatan luas panen cukup signifikan adalah komoditas jagung yaitu sebesar 177,60 persen. (BPS, 2014).

Menurut Hestiati, Bunomoti \& Sutarna (1998), bokasi merupakan kompos yang berasal dari hasil fermentasi bahan organik dengan campuran larutan Effective microorganisme4 (EM4) yang dapat digunakan pupuk organik untuk menyuburkan tanah dan meningkatkan produksi tanaman. Peranan bokasi adalah secara cepat untuk memenuhi kebutuhan pupuk pada tanaman.

Selain itu, untuk mempertahankan dan meningkatkan produktivitas lahan kering dan produksi jagung dapat dilakukan dengan mencegah terjadinya degradasi lahan dan memperlambat kehilangan air tanah. Alternatif yang mungkin dapat dikembangkan adalah dengan usaha pemanfaatan mikrorganisme bermanfaat seperti Trichoderma spp.

Interaksi antara mikroba Trichoderma spp. dengan beberapa tanaman serelia memberikan peningkatan terhadap 
respon kekeringan. Selain itu dengan adanya interaksi Trichoderma spp. dengan tanaman memberikan beberapa keuntungan seperti ketahanan terhadap penyakit, merangsang pertumbuhan tanaman dan toleransi terhadap cekaman abiotik termasuk kekeringan (Shukla et al., 2012). Dari uraian yang telah dikemukakan tersebut, dianggap perlu melakukan penelitian pengaruh Tricoderma spp dan bokasi terhadap pertumbuhan jagung manis pada lahan alluvial.

\section{METODE}

Penelitian ini dilaksanakan pada bulan oktober desember 2018 di desa Antibar Kecamatan Mempawah Timur Kabupaten Mempawah Provinsi Kalimantan Barat.

Penelitian ini menggunakan Rancangan Acak Kelompok (RAK) dengan pola faktorial yang terdiri atas dua faktor, faktor pertama yaitu jenis bokashi yang meliputi :

b0 = Tanpa Bokashi

b1 = Bokashi dari kotoran sapi

b2 = Bokashi dari kotoran ayam

b3 = Bokashi dari limbah ikan

Sedangkan faktor kedua adalah yaitu inokulasi Trichoderma spp.

s0 = 0 tanpa inokulasi Trichoderma spp

s1 = inokulasi Trichoderma spp

s2 = inokulasi Trichoderma spp + pupuk hayati

Terdapat 12 kombinasi dua perlakuan jenis bokashi dan inokulasi yaitu (b0s0), (b0s1), (b0s2), (b1s0), (b1s1), (b1s2), (b2s0), (b2s1), (b2s2), (b3s0), (b3s1), (b3s2) yang di replikasi sebanyak tiga kali, sehingga sehingga diperoleh tiga puluh enam petak percobaan dengan jarak tanam jagung manis $65 \mathrm{~cm} \times 25 \mathrm{~cm}$.

\section{HASIL DAN PEMBAHASAN}

\section{Pertumbuhan Tanaman Jagung}

\section{a. Tinggi Tanaman}

Hasil analisis data tinggi tanaman terlihat bahwa perlakuan penggunaan Trichoderma terlihat berbeda nyata, dan perlakuan macam jenis bokashi untuk jenis tanaman umur 21 hari dan umur 42 hari antara tanpa bokashi dan diberi perlakuan bokashi ada beda nyata. (data tersebut belum terbaca, mohon ditambahkan keterangan pada catatan kaki seperti * menunjukkan signifikansi,)

Hasil data menunjukkan bahwa pertumbuhan vegetatif seperti tinggi tanaman diberi perlakuan bokashi menjadi lebih baik. Hal ini disebabkan karena pada bokashi disamping mengandung unsur hara makro meskipun terbatas juga mengandung unsur hara mikro dan juga unsur pemacu pertumbuhan yang mempengaruhi pertumbuhan vegetatif seperti tinggi tanaman. Tetapi antar macam bokashi tidak beda nyata atau sama. Hal ini disebabkan karena kandungan hara pada masing masing bokashi tidak berbeda sehingga tidak mempengaruhi tinggi tanaman.

Pada perlakuan macam bokashi pada tanaman umur 42 hari terlihat bahwa bokashi dari kotoran ayam menghasilkan pertumbuhan tertinggi. Hal ini disebabkan oleh kandungan $\mathrm{N}$ pada bokashi kotoran ayam yang lebih tinggi. Senyawa Nitrogen akan merangsang pertumbuhan vegetatif tanaman yaitu menambah tinggi tanaman (Buckman, 1982).

Tabel 1. Analisis keragaman tinggi tanaman umur 21 hari

\begin{tabular}{llllll}
\hline & Derajat & \multicolumn{4}{c}{ umur tanaman } \\
\cline { 3 - 5 } Sumber Keragaman & Bebas & $21 \mathrm{hst}$ & $42 \mathrm{hst}$ & $49 \mathrm{hst}$ & F tabel $(5 \%)$ \\
\hline \hline Kelompok & 2 & $1,39 \mathrm{tn}$ & $0,37 \mathrm{tn}$ & $1,87 \mathrm{tn}$ & 3,40 \\
Bokashi & 2 & $16,14^{*}$ & $66,53^{*}$ & $50,21^{*}$ & 3,40 \\
Trichoderma & 3 & $22,54^{*}$ & $59,08^{*}$ & $85,18^{*}$ & 3,01 \\
Interaksi & 6 & $3,33^{*}$ & $5,75^{*}$ & $1,57 \mathrm{tn}$ & 2,51 \\
Galat & 24 & & & & \\
\hline Total & 35 & & & & \\
\hline
\end{tabular}

Tabel 2. Rerata pada tinggi tanaman umur 21 hari $(\mathrm{cm})$

\begin{tabular}{lllll}
\hline \multirow{2}{*}{ Perlakuan Trichoderma } & \multicolumn{4}{c}{ Jenis Bokashi } \\
\cline { 2 - 5 } & Tanpa bokashi & Bokashi kotoran sapi & Bokashi kotoran ayam & $\begin{array}{l}\text { bokashi } \\
\text { limbah ikan }\end{array}$ \\
\hline Tanpa tricodherma & $45,13 \mathrm{a}$ & $48,67 \mathrm{ab}$ & $55,47 \mathrm{bc}$ & $48,87 \mathrm{ab}$ \\
Tricodherma & $43,87 \mathrm{a}$ & $59,60 \mathrm{~cd}$ & $59,73 \mathrm{~cd}$ & $64,13 \mathrm{~d}$ \\
Tricodherma+pupuk hayati & $46,47 \mathrm{a}$ & $64,93 \mathrm{~d}$ & $59,80 \mathrm{~cd}$ & $63,33 \mathrm{~cd}$ \\
\hline \hline
\end{tabular}

Keterangan: Nilai yang diikuti huruf yang sama pada baris dan kolom yang sama berbeda tidak nyata pada uji DMRT 5\% 
Tabel 3. Rerata DMRT tinggi tanaman umur 42 hari $(\mathrm{cm})$

\begin{tabular}{|c|c|c|c|c|}
\hline \multirow[b]{2}{*}{ Perlakuan Trichoderma } & \multicolumn{4}{|l|}{ Macam Bokashi } \\
\hline & Tanpa bokashi & Bokashi kotoran sapi & Bokashi kotoran ayam & $\begin{array}{l}\text { bokashi limbah } \\
\text { ikan }\end{array}$ \\
\hline Tanpa tricodherma & $168,8 \mathrm{a}$ & $177,33 \mathrm{bc}$ & $180,93 \mathrm{c}$ & $169,8 \mathrm{a}$ \\
\hline Tricodherma & $169,7 \mathrm{a}$ & $189,27 \mathrm{~d}$ & $193,80 \mathrm{de}$ & $191,1 \mathrm{de}$ \\
\hline Tricodherma+pupuk hayati & $173,6 \mathrm{ab}$ & $194,33 \mathrm{de}$ & $196,33 \mathrm{e}$ & 193,0de \\
\hline
\end{tabular}

Keterangan: Nilai yang diikuti huruf yang sama pada baris dan kolom yang sama berbeda tidak nyata pada uji DMRT 5\%

Tabel 4. Analisis Keragaman jumlah daun tanaman umur 28 hari

\begin{tabular}{lccccc}
\hline Sumber Keragaman & Jumlah Kuadrat & Derajat Bebas & Kuadrat Tengah & F Hitung & F tabel (5\%) \\
\hline \hline Kelompok & 0,28 & 2 & 0,14 & $1,01 \mathrm{tn}$ & 3,40 \\
Bokashi & 11,03 & 2 & 5,51 & $40,35^{*}$ & 3,40 \\
Trichoderma & 22,20 & 3 & 7,40 & $54,14^{*}$ & 3,01 \\
Interaksi & 2,46 & 6 & 0,41 & $3,01^{*}$ & 2,51 \\
Galat & 3,28 & 24 & 0,14 & & \\
\hline Total & 38,97 & 35,00 & & & \\
\hline
\end{tabular}

Tabel 5. Rerata jumlah daun tanaman umur 28 hari

\begin{tabular}{lcccc}
\hline \multirow{2}{*}{ Perlakuan Tricoderma } & \multicolumn{3}{c}{ Macam Bokashi } \\
\cline { 2 - 5 } & $\begin{array}{c}\text { Tanpa } \\
\text { bokashi }\end{array}$ & $\begin{array}{c}\text { Bokashi } \\
\text { kotoran sapi }\end{array}$ & $\begin{array}{c}\text { Bokashi kotoran } \\
\text { ayam }\end{array}$ & bokashi limbah ikan \\
\hline Tanpa tricodherma & $6,53 \mathrm{a}$ & $7,53 \mathrm{~cd}$ & $8,07 \mathrm{df}$ & $7,20 \mathrm{bc}$ \\
Tricodherma & $6,80 \mathrm{ab}$ & $8,00 \mathrm{df}$ & $9,07 \mathrm{gh}$ & $8,60 \mathrm{fg}$ \\
Tricodherma+pupuk hayati & $7,00 \mathrm{abc}$ & $9,20 \mathrm{gh}$ & $9,67 \mathrm{~h}$ & $8,87 \mathrm{~g}$ \\
\hline \hline
\end{tabular}

Keterangan: Nilai yang diikuti huruf yang sama pada baris dan kolom yang sama berbeda tidak nyata pada uji DMRT 5\%.

Tabel 6. Analisis Keragaman jumlah daun tanaman umur 42 hari

\begin{tabular}{lccccc}
\hline Sumber Keragaman & Jumlah Kuadrat & Derajat Bebas & Kuadrat Tengah & F Hitung & F tabel (5\%) \\
\hline \hline Kelompok & 0,39 & 2 & 0,19 & $1,15 \operatorname{tn}$ & 3,40 \\
Bokashi & 9,98 & 2 & 4,99 & $29,53^{*}$ & 3,40 \\
Trichoderma & 5,13 & 3 & 1,71 & $10,13^{*}$ & 3,01 \\
Interaksi & 2,40 & 6 & 0,40 & $2,37 \mathrm{tn}$ & 2,51 \\
Galat & 4,05 & 24 & 0,17 & & \\
\hline Total & 21,56 & 35,00 & & & \\
\hline
\end{tabular}

Tabel 7. Rerata jumlah daun tanaman umur 42 hari

\begin{tabular}{lcccc}
\hline \multirow{2}{*}{ Perlakuan Trichoderma } & \multicolumn{4}{c}{ Macam Bokashi } \\
\cline { 2 - 5 } & Tanpa bokashi & Bokashi kotoran sapi & Bokashi kotoran ayam & bokashi limbah ikan \\
\hline Tanpa tricodherma & 7,80 & 8,67 & 8,93 & 8,67 \\
Tricodherma & 9,07 & 9,47 & 9,13 & 9,40 \\
Tricodherma+pupuk hayati & 8,87 & 10,60 & 10,13 & 9,60 \\
\hline
\end{tabular}

Keterangan: Nilai yang diikuti huruf yang sama pada baris dan kolom yang sama berbeda tidak nyata pada uji DMRT 5\%. 
Tabel 8. Hasil Analisis Keragaman diameter batang

\begin{tabular}{lccccc}
\hline Sumber Keragaman & Jumlah Kuadrat & Derajat Bebas & Kuadrat Tengah & F Hitung & F tabel (5\%) \\
\hline \hline Kelompok & 0,05 & 2 & 0,02 & $1,11 \mathrm{tn}$ & 3,40 \\
Bokashi & 2,08 & 2 & 1,04 & 47,15 & 3,40 \\
Trichoderma & 2,39 & 3 & 0,80 & 36,10 & 3,01 \\
Interaksi & 0,62 & 6 & 0,10 & 4,72 & 2,51 \\
Galat & 0,53 & 24 & 0,02 & & \\
\hline Total & 5,63 & 35,00 & & & \\
\hline
\end{tabular}

Tabel 9. Rerata diameter batang $(\mathrm{cm})$

\begin{tabular}{lcccc}
\hline \multirow{2}{*}{ Perlakuan Bokashi } & \multicolumn{3}{c}{ Macam Bokashi } \\
\cline { 2 - 5 } & Tanpa bokashi & Bokashi kotoran sapi & Bokashi kotoran ayam & bokashi limbah ikan \\
\hline Tanpa tricodherma & $1,96 \mathrm{a}$ & $2,26 \mathrm{bc}$ & $2,15 \mathrm{abc}$ & $2,01 \mathrm{ab}$ \\
$\begin{array}{l}\text { Tricodherma } \\
\text { Tricodherma+pupuk }\end{array}$ & $2,15 \mathrm{abc}$ & $2,63 \mathrm{de}$ & $2,89 \mathrm{ef}$ & $2,35 \mathrm{~cd}$ \\
hayati & $2,21 \mathrm{abc}$ & $2,85 \mathrm{ef}$ & $3,22 \mathrm{f}$ & $2,39 \mathrm{~cd}$ \\
\hline rata rata & $2,10 \mathrm{a}$ & $2,58 \mathrm{~b}$ & $2,75 \mathrm{c}$ & $2,25 \mathrm{a}$ \\
\hline
\end{tabular}

Ket: Nilai yang diikuti huruf yang sama pada baris dan kolom yang sama berbeda tidak nyata pada uji DMRT 5\%

Tabel 10. Analisis keragaman LPR

\begin{tabular}{lccccc}
\hline & & \multicolumn{3}{c}{ LPR } & \\
\cline { 3 - 5 } Sumber Keragaman & Derajat Bebas & 3MST & 5MST & 7MST & F tabel (5\%) \\
\hline \hline Kelompok & 2 & $0,25 \mathrm{tn}$ & $3 \mathrm{tn}$ & $1,2 \mathrm{tn}$ & 3,40 \\
Bokashi & 2 & $1,10 \mathrm{tn}$ & $1,60 \mathrm{tn}$ & $2,23 \mathrm{tn}$ & 3,40 \\
Trichoderma & 3 & $0,75 \mathrm{tn}$ & $2,77 \mathrm{tn}$ & $4,89^{*}$ & 3,01 \\
Interaksi & 6 & $0,49 \mathrm{tn}$ & $0,84 \mathrm{tn}$ & $0,26 \mathrm{tn}$ & 2,51 \\
Galat & 24 & & & & \\
\hline Total & 35 & & & & \\
\hline
\end{tabular}

\section{b. Jumlah Daun}

Daun memiliki fungsi penting yaitu, (1) Menghasilkan oksigen dari hasil proses fotosintesa, (2) melepaskan sejumlah air berlebih yang diabsorbsi oleh akar melalui stomata daun, (3) membentuk makanan dari mineral air yang diambil dari tanah dengan karbon dan oksigen yang diambil dari udara untuk bahan pembentukan karbohidrat, (4) sebagai penangkap cahaya matahari yang kmudian digunakan untuk fotosistesis melalui klorofil pada daun tersebut. Unsur $\mathrm{N}$ dalam hal ini merupakan bagian utuh dari sruktur klorofil, warna hijau daun (Gardner et al.,1991).

Hasil uji lanjutan Duncan pada jumlah daun tanaman umur 28 hari menunjukkan macam bokashi terlihat berbeda nyata, namun pada umur 42 hari antar macam bokashi tidak berbeda nyata dan interaksi antar perlakuan tidak beda nyata. Tetapi perlakuan antara tanpa bokashi dan diberi bokashi terlihat berbeda nyata.

\section{c. Diameter Batang}

Dari hasil anova menunjukkan bahwa perlakuan bokashi berpengaruh nyata terhadap pertumbuhan jumlah daun tanaman jagung. Hal ini menunjukkan bahwa unsur $\mathrm{N}$ dan unsur hara makro yang terdapat pada pupuk bokashi sangat mempengaruhi pertumbuhan daun. Hai ini disebabkan oleh peran unsur hara makro $\mathrm{N}$ pada bokashi dan hara mikro seperti FE, Mn, Bo, Mg dsb pada bokashi sangat berperan meningkatkan protein, asam nukleat, warna hijau dan jumlah klorofil untuk meningkatkan proses fotosintesis (Agustina, 1980). Disamping itu unsur hara makro dan mikro pada bokashi juga mengandung zat pemacu pertumbuhan yang dapat memacu pertumbuhan daun (Gardner, dkk.,1991).

Hasil analisis keragaman pengaruh macam bokashi dan Trichoderma menunjukkan pengaruh nyata terhadap diameter batang tanaman jagung. Diameter batang didefinisikan sebagai panjang garis antara dua buah titik pada lingkaran disekeliling batang yang melalui titik pusat (sumbu) batang. Diameter batang adalah dimensi tanaman yang paling mudah diukur terutama pada bagian bawah. Diameter batang diukur pada bagian bawah tanaman menggunakan jangka sorong. Hasil analisis keragaman diameter batang dapat dilihat dalam Tabel 8. 
Pengaruh pemberian macam bokashi terdapat beda nyata dalam mempengaruhi diammeter batang jagung. Hal ini berdasarkan Retno dan Darminanti (2009) yang menyatakan kandungan hara yang cukup didalam tanah akan menyebabkan pertumbuhan vegetatif tanaman jagung menjadi baik. Perlakuan bokashi dari kotoran ayam dengan tambahan trichoderma dan pupuk hayati memberikan hasil yang paling baik.

\section{d. Laju Pertumbuhan Relatif}

Laju pertumbuhan relatif adalah efisiensi pembentukan biomasa baru setiap satuan biomasa awal. Dari hasil analisis data terlihat bahwa pengaruh bokashi tidak signifikan. Unsur $\mathrm{N}$ berinteraksi dengan pupuk makro dan mikro pada bokashi tersebut meningkatkan aktivitas organisme tanah dan memperbaiki sifat kimia dan fisika tanah sehingga kandungan hara yang diserap tanaman untuk pertumbuhan di dalam menghasilkan biomassa tanaman makin besar. Distribusi akumulasi bahan kering pada bagian bagian tanaman seperti akar, batang, daun dan bagian generatif dapat mencerminkan produktivitas tanaman. Hasil dari data LPR kemampuan tanaman menghasilkan bahan kering hasil asimilasi tiap satuan bobot kering awal tiap satuan waktu terlihat bahwa bokashi dari kotoran ayam menghasilkan LPR yang lebih kecil, namun jika kita hubungkan dengan bobot hasil tanaman, tanaman dengan nilai LPR yang lebih kecil menghasilkan bobot tongkol yang lebih besar. Hal ini menunjukkan distribusi dari biomassa tanaman tersebut lebih diefisenkan untuk penambahan bobot hasil tanama

\section{Hasil Tanaman jagung}

\section{a. Bobot Tongkol Berkelobot}

Hasil analisis menunjukkan bahwa perlakuan macam bokashi terdapat beda nyata dalam mempengaruhi berat tongkol berklobot. Hal ini disebabkan faktor unsur yang mempengaruhi berat tongkol berklobot seperti $\mathrm{P}$ dan $\mathrm{K}$ pada pupuk bokashi dan mikroba pelarut $\mathrm{P}$ pada pupuk hayati.

Dari Tabel 11. terlihat bahwa rata rata bokashi dari kotoran ayam dengan penambahan trichoderma dan pupuk hayati menghasilkan berat tongkol berklobot paling besar. Berarti kombinasi bokashi kotoran ayam dengan penambahan tricodherma dan pupuk hayati yang mempunyai kandungan $\mathrm{N}$ yang relatif tinggi dibandingkan pupuk bokashi yang lain dapat menghasilkan berat tongkol yang optimum. Menurut
Isbandi (1994), unsur $\mathrm{N}$ dalam hal itu berfungsi penyusun protein, assam nukleat, klorofil dan senyawa organik lainnya. Klorofil mempengaruhi fotosintesis yang dapat menghasilkan karbohidrat yang disimpan pada tongkol jagung. Sedangkan unsur unsur mikro pada bokashi berperan dalam membantu aktivitas enzim dan fotosintesis.

\section{b. Bobot Tongkol Tanpa Kelobot}

Perlakuan macam bokashi dan tricoderma berpengaruh nyata terhadap berat tongkol tanpa kelobot. Perlakuan bokashi dari kotoran sapi menghasilkan rata rata berat tongkol tanpa kelobot paling tinggi. Hal ini disebabkan kandungan $\mathrm{N}$ dan $\mathrm{P}$ pada pupuk bokashi yang mempengaruhi pertumbuhan vegetatifnya dan kandungan $\mathrm{P}$ untuk pertumbuhan generatif pada pengisian karbohidrat pada biji.

Peranan $\mathrm{P}$ adalah pembentuk senyawa adenosin difosfat (ADP) dan Adenosin Tri Fosfat (ATP) yang mempengaruhi transformasi energi dalam tanaman, dan berperan dalam proses metabolisme (Anonim, 1990). Karbohidrat merupakan hasil fotosintesis yang salah satunya dapat terjadi akibat peranan zat hijau daun atau klorofil daun. Hal ini disebabkan jumlah $\mathrm{N}$ tersedia relatif tinggi pada perlakuan tersebut. Perlu diketahui bahwa fungsi $\mathrm{N}$ adalah untuk pembentukan protein, klorofil, dan warna hijau (Gardner, 1991).

\section{c. Panjang Tongkol}

Hasil analisis keragaman menunjukkan bahwa perlakuan bokashi berpengaruh signifikan terhadap panjang tongkol. Pada Tabel dapat terlihat bokashi dari kotoran sapi dan bokashi dari kotoran ayam menghasilkan panjang tongkol paling tinggi. Namun pada bokashi kotoran sapi dan bokashi kotoran ayam perbedaannya tidak nyata, hal ini disebabkan kandungan $\mathrm{N}$ pada kedua macam bokashi tersebut perbedaannya relatif kecil sehingga kurang berpengaruh terhadap panjang tongkol.

Rata rata perlakuan bokashi kotoran ayam terlihat menghasilkan panjang tongkol yang relatif paling besar. Hal ini adalah karena kandungan $\mathrm{N}$ nya adalah yang tertinggi, dimana fungsi $\mathrm{N}$ adalah menyusun zat hijau daun, protein dan lemak serta membantu pertumbuhan vegetatif (Seputro, 1996). Disamping itu kandungan $\mathrm{P}_{2} \mathrm{O}$ pada bokashi kotoran ayam juga tinggi dimana unsur phospat tersebut berperan dalam pembentukan karbohidrat (Anonim, 1990). Jadi pupuk bokashi kotoran ayam meperbaiki kualitas jagung dengan membuat ukuran tongkol menjadi relatif lebih panjang.

Tabel 11. Analisis Keragaman Rata rata berat tongkol berkelobot

\begin{tabular}{lccccc}
\hline Sumber Keragaman & Jumlah Kuadrat & Derajat Bebas & Kuadrat Tengah & F Hitung & F tabel (5\%) \\
\hline \hline Kelompok & 20,34 & 2 & 10,17 & 0,57 tn & 3,40 \\
Bokashi & 16828,11 & 2 & 8414,05 & $472,43^{*}$ & 3,40 \\
Trichoderma & 16687,81 & 3 & 5562,60 & $312,33^{*}$ & 3,01 \\
Interaksi & 6706,09 & 6 & 1117,68 & $62,76^{*}$ & 2,51 \\
Galat & 427,44 & 24 & 17,81 & & \\
\hline Total & 40649,45 & 35 & & & \\
\hline
\end{tabular}


Tabel 12. Rerata berat tongkol berkelobot (gram)

\begin{tabular}{lcccc}
\hline \multirow{2}{*}{ Perlakuan } & \multicolumn{4}{c}{ Macam Bokashi } \\
\cline { 2 - 5 } & Tanpa bokashi & Bokashi kotoran sapi & Bokashi kotoran ayam & bokashi limbah ikan \\
\hline Tanpa tricodherma & $467,133 \mathrm{a}$ & $484,533 \mathrm{c}$ & $480,8 \mathrm{c}$ & $479,867 \mathrm{bc}$ \\
Tricodherma & $473,267 \mathrm{ab}$ & $523,733 \mathrm{e}$ & $522,8 \mathrm{e}$ & $501,867 \mathrm{~d}$ \\
Tricodherma+pupuk & $478,933 \mathrm{bc}$ & $565,8 \mathrm{f}$ & $570,267 \mathrm{f}$ & $509,133 \mathrm{~d}$ \\
hayati & & & & \\
\hline
\end{tabular}

Ket: Nilai yang diikuti huruf yang sama pada baris dan kolom yang sama berbeda tidak nyata pada uji DMRT 5\%

Tabel 13. Analisis keragaman berat tongkol tanpa kelobot

\begin{tabular}{llllll}
\hline Sumber & & & & \\
Keragaman & Jumlah Kuadrat & Derajat Bebas & Kuadrat Tengah & F Hitung & F tabel (5\%) \\
\hline \hline Kelompok & 116,19 & 2 & 58,09 & 1,62 tn & 3,40 \\
Bokashi & 2109,89 & 2 & 1054,94 & $29,35^{*}$ & 3,40 \\
Trichoderma & 2969,39 & 3 & 989,80 & $27,54^{*}$ & 3,01 \\
Interaksi & 927,63 & 6 & 154,61 & $4,30^{*}$ & 2,51 \\
Galat & 862,72 & 24 & 35,95 & & \\
\hline Total & 6869,63 & 35 & & & \\
\hline
\end{tabular}

Tabel 14. Rerata berat tongkol tanpa kelobot

\begin{tabular}{lcccc}
\hline \multirow{2}{*}{ Perlakuan Trichoderma } & & \multicolumn{3}{c}{ Macam Bokashi } \\
& Tanpa bokashi & Bokashi kotoran sapi & Bokashi kotoran ayam & bokashi limbah ikan \\
\hline Tanpa tricodherma & $304 \mathrm{a}$ & $321,2 \mathrm{bc}$ & $312,73 \mathrm{ab}$ & $313 \mathrm{ab}$ \\
Tricodherma & $314,53 \mathrm{~b}$ & $335,53 \mathrm{de}$ & $328,13 \mathrm{~cd}$ & $316,27 \mathrm{~b}$ \\
Tricodherma+pupuk hayati & $314,67 \mathrm{~b}$ & $340,867 \mathrm{e}$ & $350,13 \mathrm{f}$ & $319,93 \mathrm{bc}$ \\
\hline
\end{tabular}

Ket: Nilai yang diikuti huruf yang sama pada baris dan kolom yang sama berbeda tidak nyata pada uji DMRT 5\%

Tabel 15. Analisis Keragaman Rata-rata panjang tongkol

\begin{tabular}{lllccc}
\hline Sumber Keragaman & Jumlah Kuadrat & Derajat Bebas & Kuadrat Tengah & F Hitung & F tabel (5\%) \\
\hline \hline Kelompok & 0,78 & 2 & 0,39 & $2,58 \operatorname{tn}$ & 3,40 \\
Bokashi & 30,11 & 2 & 15,05 & $99,62 *$ & 3,40 \\
Trichoderma & 28,71 & 3 & 9,57 & $63,32 *$ & 3,01 \\
Interaksi & 4,72 & 6 & 0,79 & $5,21 *$ & 2,51 \\
Galat & 3,63 & 24 & 0,15 & & \\
\hline Total & 67,16 & 35 & & & \\
\hline
\end{tabular}

Tabel 16. Rerata panjang tongkol $(\mathrm{cm})$

\begin{tabular}{|c|c|c|c|c|}
\hline \multirow[b]{2}{*}{ Perlakuan Trichoderma } & \multicolumn{4}{|c|}{ Macam Bokashi } \\
\hline & Tanpa bokashi & $\begin{array}{l}\text { Bokashi kotoran } \\
\text { sapi }\end{array}$ & Bokashi kotoran ayam & $\begin{array}{c}\text { bokashi limbah } \\
\text { ikan } \\
\end{array}$ \\
\hline Tanpa tricodherma & $18,40 \mathrm{a}$ & $20,33 d$ & $19,80 \mathrm{~cd}$ & $18,00 \mathrm{a}$ \\
\hline Tricodherma & $19,27 b$ & $20,93 \mathrm{e}$ & $21,33 \mathrm{ef}$ & $20,07 \mathrm{~cd}$ \\
\hline Tricodherma+pupuk hayati & $19,60 \mathrm{bc}$ & $22,00 \mathrm{fg}$ & $22,53 \mathrm{~g}$ & $21,33 \mathrm{ef}$ \\
\hline
\end{tabular}

Keterangan: Nilai yang diikuti huruf yang sama pada baris dan kolom yang sama berbeda tidak nyata pada uji DMRT 5\%. 
Tabel 17. Analisis keragaman diameter tongkol Jagung

\begin{tabular}{lccccc}
\hline Sumber Keragaman & Jumlah Kuadrat & Derajat Bebas & Kuadrat Tengah & F Hitung & F tabel (5\%) \\
\hline \hline Kelompok & 0,0054 & 2 & 0,0027 & 1,6395 tn & 3,40 \\
Bokashi & 0,0422 & 2 & 0,0211 & $12,9048^{*}$ & 3,40 \\
Trichoderma & 0,0294 & 3 & 0,0098 & $5,9955^{*}$ & 3,01 \\
Interaksi & 0,0028 & 6 & 0,0005 & 0,2880 tn & 2,51 \\
Galat & 0,0392 & 24 & 0,0016 & & \\
\hline Total & 0,0392 & 35 & & & \\
\hline
\end{tabular}

Tabel 18. Rerata diameter tongkol jagung $(\mathrm{cm})$

\begin{tabular}{|c|c|c|c|c|c|}
\hline \multirow{2}{*}{ Perlakuan Bokashi } & \multicolumn{4}{|c|}{ Macam Bokhasi } & \multirow{2}{*}{ Rata ratc } \\
\hline & Tanpa bokashi & B.kotoran sapi & B.kotoran ayam & B. limbah ikan & \\
\hline Tanpa tricodherma & 5,24 & 5,29 & 5,32 & 5,24 & $5,27 \mathrm{a}$ \\
\hline Tricodherma & 5,33 & 5,37 & 5,38 & 5,32 & $5,35 b$ \\
\hline $\begin{array}{l}\text { Tricodherma+pupuk } \\
\text { hayati }\end{array}$ & 5,31 & 5,33 & 5,39 & 5,32 & $5,34 \mathrm{~b}$ \\
\hline rata rata & $5,30 \mathrm{a}$ & $5,33 \mathrm{a}$ & $5,36 a$ & $5,29 a$ & \\
\hline
\end{tabular}

Keterangan: Nilai yang diikuti huruf yang sama pada baris dan kolom yang sama berbeda tidak nyata pada uji DMRT $5 \%$.

Tabel 19. Analisis Ragam Bobot Berangkasan Kering

\begin{tabular}{lccccc}
\hline Sumber Keragaman & Jumlah Kuadrat & Derajat Bebas & Kuadrat Tengah & F Hitung & F tabel (5\%) \\
\hline \hline Kelompok & 4,87 & 2 & 2,43 & 0,02 tn & 3,40 \\
Bokashi & 72599,04 & 2 & 36299,52 & $256,33^{*}$ & 3,40 \\
Trichoderma & 61780,45 & 3 & 20593,48 & $145,42^{*}$ & 3,01 \\
Interaksi & 17825,53 & 6 & 2970,92 & $20,98 *$ & 2,51 \\
Galat & 3398,69 & 24 & 141,61 & & \\
\hline Total & 155603,72 & 35 & & & \\
\hline
\end{tabular}

Tabel 20. Rerata Bobot Berangkasan Kering (g)

\begin{tabular}{lcccc}
\hline \multirow{2}{*}{ Perlakuan Bokashi } & \multicolumn{4}{c}{ Macam Bokashi } \\
\cline { 2 - 5 } & Tanpa bokashi & Bokashi kotoran sapi & Bokashi kotoran ayam & bokashi limbah ikan \\
\hline Tanpa tricodherma & $122,33 \mathrm{a}$ & $153,07 \mathrm{c}$ & $160,00 \mathrm{c}$ & $141,60 \mathrm{abc}$ \\
Tricodherma & $131,07 \mathrm{ab}$ & $244,47 \mathrm{~d}$ & $238,20 \mathrm{~d}$ & $239,73 \mathrm{~d}$ \\
Tricodherma+pupuk hayati & $147,40 \mathrm{bc}$ & $296,87 \mathrm{e}$ & $312,93 \mathrm{e}$ & $254,47 \mathrm{~d}$ \\
\hline
\end{tabular}

Keterangan: Nilai yang diikuti huruf yang sama pada baris dan kolom yang sama berbeda tidak nyata pada uji DMRT 5\%

\section{d. Diameter Tongkol}

Hasil analisis diameter tongkol memperlihatkan ada beda nyata antara macam perlakuan, dan tidak ada interaksi antar perlakuan.

Dari Tabel 17. dapat dilihat hasil diameter tertinggi didapat dari perlakuan bokashi kotoran ayam dengan trichoderma ditambah pupuk hayati. Walaupun tidak berbeda nyata dengan perlakuan yang lain. Hal ini dikarenakan unur $\mathrm{N}$ yang tidak signifikan atau relatif kecil dari perlakuan yang lain. Kemungkinan lain adalah diameter tongkol memang semuanya sudah maksimal sesuai dengan kemampuan tanaman.

\section{e. Bobot Berangkasan Kering}

Hasil analisis bobot berangkasan kering menunjukkan perlakuan macam bokashi dan trichoderma berbeda nyata, dan interaksi kedua perlakuan tersebut berbeda nyata. Hal ini menunjukkan bahwa berat berangkasan yang merupakan total dari berat tanaman kering dipengaruhi oleh biomassa yang tersusun oleh unsur makro dan mikro dan unsur unsur tersebut terdapat pada pupuk bokashi meskipun kadarnya relatif sangat kecil. Keduanya mempunyai sinergi untuk bersama sama membangun biomassa tanaman jagung. Pada Tabel 19. menunjukkan bahwa pupuk bokashi kotoran ayam dengan penambahan trichoderma dan pupuk hayati menghasilkan rata rata berat berangkasan kering terbesar. Ini menunjukkan peranan unsur $\mathrm{N}, \mathrm{P}$ dan KTK relatif tinggi disamping itu $\mathrm{C} / \mathrm{N}$ rasio relatif rendah $\mathrm{C}$ organik tinggi sehingga unsur makronya adalah sangat besar didalam pembentukkan biomassa yang selanjutnya berkembang sampai menjelang panen, dimana 
berlangsung pembentukan karbohidrat hasil fotosintesis pada biji.

\section{KESIMPULAN}

Interaksi bokashi dengan penambahan trichoderma+pupuk hayati yang diperkaya mikroba berpengaruh nyata terhadap pertumbuhan tinggi tanaman, jumlah daun, berat berakasan kering dan hasil tanaman jagung. Pertumbuhan dan hasil produksi yang paling baik dicapai dengan perlakuan bokashi kotoran ayam dengan penambahan trichoderma dan pupuk hayati.

\section{DAFTAR PUSTAKA}

Agustina, L. (1980). Nutrisi Tanaman. Rineka Cipta, Jakarta. 40 hal.

Arwiyanto. (2003). Pengembangan Agen Hayati untuk Tanaman Holtikultura. Departemen Pertanian Jakarta.

Barnett, H.L. \& Hunter B. B. (1972). Ilustrated Genera of Imperfect Fungi. Virginia: Burgers Publishing Company.

Buckman, H.O. \& Brady, N.C. (1982). Ilmu Tanah (Terjemahan Soengiman). Bharatara Karya Aksara. Jakarta. 788 hlm.

BPS. 2014. Statistik Tanaman Padi dan Palawija. BPS. Mempawah.

Cuevas, V.C. (1997). Rapid Composting Tecnology In The Philippinnes: Its Role In Producing Good-Quality Organic Fertilizers. Intitute of Biological Scienes (IBS). Philippines.

Gardner, F.P, Pearce, R.B, \& Mitchell R..L. (1991). Physiologi of Crop Plants. Terjemahan Oleh Herawati Susilo. Fisiologi Tanaman Budidaya. Pendamping Subianto. UI-Press. Jakarta.

Gultom, J.M. (2008). Pengaruh Pemberian Beberapa Jamur Antaginis dengan Berbagai Tingkat Konsentrasi untuk menekan Pertumbuhan Jamur Phytium sp. Penyebab Rebah Kecambah Pada Tanaman Tembakau (Nicotiania Tabaccum L).

Hapsari, B. (2003). Stop Fusarium dengan Tricodherma. Trubus 404-XXX. Hal 42-43.

Hestiati, E., Bunomoti, T., \& Sutarna, I. G. S. (1998). Pengaruh Pemberian Zat Pengatur Tumbuh Natrium Nitrofenol dan Pupuk Bokashi Terhadap Pertumbuhan Tomat. Buletin Kyusei Nature Farming, Vol. 01. Jakarta.
Isbandi, D., Wartoyo, \& Soeharto. (1994). Fisiologi Pertumbuhan dan Perkembangan Tanaman I dan II. Universitas Sebelas Maret, Surakarta. 275 Hal.

Nasir. (2007). Tehnik Pembuatan Bokashi. http://www.disperternak.pandeglang.go.id. Diakses pada tanggal 22 Oktober 2015

Nurhayati, H. (2001). Pengaruh Pemberian Tricodherma sp Terhadap Daya Infeksi dan ketahanan Hidup Sclerotium roflsii pada akar bibit Cabai. Skripsi. Fakultas Pertanian Untad. Palu.

Purwantisari, S. \& Hastuti, R.B. (2009). Uji Antagonisme Jamur Patogen Phytophthora infestans Penyebab Penyakit Busuk Daun dan Umbi Tanaman Kentang dengan menggunakan Trichoderma spp. Isolat Lokal. 11(1):24-32

Retno \& Darminanti. S. (2009). Pengaruh Dosis Kompos Dengan Stimulator Tricoderma Terhadap Pertumbuhan dan Produksi Tanaman Jagung (Zea mays L.).Varietas pioner - 11 Pada Lahan Kering. Jurnal BIOMA, Vol . 11. No 2. Hal 69 -75.

Saravanakumar, K., Arasu, V.S. \& Kathiresan, K. (2013). Effect of Trichoderma on soil phosphate solubilization and growth improvement of Avicennia marina. Aquatic Botany, 104: 101-105.

Semangun, H. (1996). Penyakit Penyakit Penting Tanaman Hortikultura di Indonesia. UGM-Press. Yogyakarta.

Setiawan, K. 1(993). Pertumbuhan, produksi dan kadar sukrosa tiga varietas jagung manis akibat pemberian berbagai taraf dosis urea. Jurnal Holtikultura, Vol 3 No 12. Jakarta.

Sharma, P., Kumar, V. P., Ramesh, R., Saravan, K., Deep, S., Sharma, M., Manesh, S., \& Dinesh, S. (2011). Biocontrol genes from Tricodherma species: A. Review. African Journal of Biotechnoloy 10 (86): 19898-19907.

Shukla, N., Awasthi, R.P., Rawat, L., \& J. Kumar. (2012). Biochemical and physiological response of rice (Oriza Sativa L) as influenced by Tricodherma harzianum under draught stress. Plant Physiology and Biochemistry 54: 78-88.

Singh, R. K. (2010). Trichoderma: A bio-control agent for management of soil borne diseases. http://agropedia.iitk.ac.in.

Sudaryanto, T., Kustiari, R., \& Saliem, H. P. (2010). Analisis sumber daya lahan menuju ketahanan pangan berkelanjutan. Badan Penelitian dan pengembangan Pertanian. Jakarta. 
Sutanto, R. (2002). Penerapan Pertanian Organik Permasyarakatan dan Pengembangannya. Yogyakarta: Kanisius.

Suwahyono. (2004). Trichoderma harzianum Indigeneous Untuk Pengendalian Hayati. Studi Dasar Menuju Komersialissi dalam Panduan Seminar Biologi. Yogyakarta : Fakultas Biologi UGM.

Tindaon, H. (2008). Pengaruh jamur Antagonis Trichoderma
Harzianum dan Pupuk Organik Untuk mengendalikan Patogen Tular Tanah Sclerotium roflsii Sacc pada Tanaman kedelai (Glycine Max L) di rumah kasa. http://repository.usu.ac.id/bitstream/123456789/7723/ 1/09E00733.pdf. pada tanggal 10 Maret 2015.

Trianto \& Gunawan Sumantri. (2003). Pengembangan Trichoderma spp. Untuk Pengendalian OPT Pangan dan Holtikultura. Makalah. Lab. PHPT Wilayah Semarang. 